\title{
Paul Shore
}

Narratives of Adversity. Jesuits in the Eastern Peripheries of the Habsburg Realms (1640-1773). Budapest, New York: Central European University Press, 2012. Pp. 384. $\mathrm{Hb}, 55.00$ Euros.

Paul Shore has published important contributions to the history of the Jesuits in the eastern part of early modern Europe, notably his book Jesuits and the Politics of Religious Pluralism in Eighteenth-Century Transylvania (Ashgate, 2007). Now he has published a book on the Jesuits in the eastern parts of the Habsburg realms during the seventeenth and eighteenth centuries. The peripheries in question were the countries of the historic kingdom of Hungary: Upper Hungary or present-day Slovakia (under Habsburg rule) and more or less independent Transylvania and the center of historic Hungary in the Danube basin, occupied by the Turks from the mid-seventeenth century and reconquered by the imperial army after 1683 . The book also has a small chapter about the Jesuit mission in Belgrade.

The Jesuits came to Trnava in Upper Hungary, invited by the archbishop of Esztergom, in 1554 to rebuild Catholicism in this Protestant-influenced area: they included Juan de Vitoria from Vienna and later the Hungarian Gregorius Vásárhelyi, the translator of Canisius's catechism into Hungarian, who died after many years in Upper Hungary at Cluj in Transylvania. The Jesuits made much of the experience of adversity and portrayed their own work as heroic in the context of baroque piety and an understanding of the world as a place "where the will of God was evident everywhere" (3). For instance, in his Manductio of 1687 , the superior general of the Society, Tirso González de Santalla, portrayed the Jesuits' work in Hungary as glorious and saw them as Christian heroes in the struggle against the "Mohammedan Hydra" (39). But the Muslim Turks were not the only enemies. There were also Protestants. Here, Shore turns to events in Košice, at that time a small town in present-day Slovakia, a fortress outside the Turkish part of Hungary, sometimes in Habsburg possession, sometimes held by national insurgents against the Habsburgs. In 1603, when Košice was under Habsburg rule, the cathedral of St. Elizabeth used by the Lutherans for many decades was given to the Jesuits. In 1619, the Calvinist George I Rákóczi, who became prince of Transylvania in 1630, occupied Košice and allowed the executions of the Jesuits István Pongrácz from Transylvania and Melchior Grodziecki from Poland, as well as the Croatian secular priest Marko of Križevci-all three were beatified by Pius X in 1905 and canonized by John Paul II in 1995. "In the Jesuit narrative of ultimative triumph over adversity, however, Košice possessed another monument far more significant than its cathedral... the site of the martyrdom of three [sic] Jesuits at the hands of Calvinist soldiers" (43). 
Shore analyses these narratives of Jesuit experience up to the suppression of the order in 1773. He has consulted reports to provincials or to the superior general in Rome collected in the Archivum Romanum Societatis Iesu in Rome, private letters of Jesuits in many archives and libraries, unpublished diaries (notably those held by the Eötvös Loránd University Library in Budapest), and printed books. The latter include the aforementioned Manductio of González de Santalla (missing in Shore's bibliography which he only quotes from Emanuele Colombo, "Jesuits and Islam in seventeenth-century Europe," an article published in 2009), Mathias Tanner, Societas Jesu usque ad sanguinis et vitae profusionem militans [...] (1675), and by the same author Societas Jesu Apostolorum Imitatrix [...] (1694), and Philipp Alegambe's Mortes illustres et gesta eorum de Societate Jesu (1657). Works like these led to historical studies which Shore describes in his very interesting chapter "In Pursuit of History" (211-241). "Historical scholarship was a key element of Jesuit literary culture in the seventeenth century [...]. During the first two centuries of its existence, the histories composed and compiled by Jesuits defined the narrative of the Society offered to outsiders, [and] cultivated a vocabulary among Jesuits for expressing the Jesuit experience" (211). Shore shows the key role "Jesuits played in laying the foundations of historical scholarship" (212) although the pre-suppression Jesuit historians were sometimes uncritical in their approach to sources. One such was Melchior Inchoffer, author of the Annales ecclesiastici regni Hungariae of 1644 , who claimed "to have located the original papal bull bestowed on St. Stephen by Sylvester II that granted the king apostolic rights" (213). Inchoffer supported the legend of the Holy Crown of Hungary which the pope supposedly sent to King Stephen in 1000 and the title Apostolic King or Apostolic Majesty claimed by the kings of Hungary until 1918, and which Pope Clement XIII granted to Maria Theresia in 1758. Shore speaks about Jesuit Humanism and writes: "Historical events were for Jesuits, as they were for their Protestant rivals, a book in which the will of God was written ... The Jesuit historians of High Baroque Hungary shared with their colleagues elsewhere this 'Jesuit' humanistic style and likewise embraced a view of ultimate causality that went far beyond empirical evidence and strove for a more teleological view of events" (215). But what is this kind of historical writing compared with the works of Humanist historians like Leonardo Bruni, Niccolò Machiavelli, Francesco Guicciardini or Lorenzo Valla in Renaissance Florence? Nonetheless, younger Jesuit historians in Hungary "laid the foundation for the criticallybased historical work of the early nineteenth century and became major players in the creation of a Hungarian national consciousness derived from the retelling of Hungarian history" (225). 
The book has no map of Jesuit residences in Hungary and Transylvania, but the "Register of Geographical Names" (380-384) with the names in Hungarian, Slovak, German, Romanian, Serbian/Croatian (and partly in Ukrainian and in English) is very helpful. It is advantageous that Shore's book was published at the same time as Julia Anna Riedel's Bildungsreform und geistliches Ordenswesen im Ungarn der Aufklärung. Die Schulen der Piaristen unter Maria Theresia und Joseph II (Stuttgart, 2012). In this exciting field of study we can welcome two important works on two important religious orders, Jesuits and Piarists, in early-modern Hungary.

\author{
Harm Klueting \\ University of Cologne and University of Fribourg \\ Harm.Klueting@t-online.de
}

